MATEC Web of Conferences 13,03006 (2014)

DOI: $10.1051 /$ matecconf/ 20141303006

(C) Owned by the authors, published by EDP Sciences, 2014

\title{
Risk matrix model for rotating equipment
}

\author{
Rano Khan Wassan ${ }^{1, a}$, Mohd Amin Abd Majid ${ }^{2}$ and Ainul Akmar Mokhtar ${ }^{3}$ \\ ${ }^{123}$ Mechanical Engineering Department, Universiti Teknologi PETRONAS, Bandar Seri Iskandar, \\ 31750 Tronoh, Perak, Malaysia
}

\begin{abstract}
Different industries have various residual risk levels for their rotating equipment. Accordingly the occurrence rate of the failures and associated failure consequences categories are different. Thus, a generalized risk matrix model is developed in this study which can fit various available risk matrix standards. This generalized risk matrix will be helpful to develop new risk matrix, to fit the required risk assessment scenario for rotating equipment. Power generation system was taken as case study. It was observed that eight subsystems were under risk. Only vibration monitor system was under high risk category, while remaining seven subsystems were under serious and medium risk categories.
\end{abstract}

\section{Introduction}

To define risk of a typical rotating equipment is quite difficult, because of broad range of rotating equipment present having various features like speeds, sizes, use etc [1]. Besides, there is wide variety of rotating equipment. In general any rotating equipment has three major components, which are rotor, bearings and supporting structure known as foundation. Rotating equipment are critical for many industries. Failure of rotating equipment could result to risk related issues [2].

The risk assessment matrix is a classical technique of system or component risk analysis [3]. This technique can provide the benefit to identify risk of rotating equipment as a combination of two parameters; consequences and probability of failure or failure rate. These parameters can be estimated using statistical method and calculations or by engineering judgment [3]. Risk assessment matrix gives both, objective and the subjective evaluation of risk and identifies risk acceptability for system [4]. Implementation of quantified scales to the risk assessment matrix axes has become an accepted practice and is supported by certain standards, which improved the decision making.

Variety of risk assessment matrix are available from various standards like Risk Management Standards : AS/NZS 4360:2004 and MIL-STD-882 [5]. Risk assessment matrix, while staying factual to the Occupational Health and Safety authorities, can be frequently customized to fit a specific work circumstances. Risk assessment can be performed by three approaches, namely; quantitative, qualitative and semi-quantitative approach [5].

The categorization of the failure consequences and probability depends on the type of activity risk involved, in this case rotating equipment. Generally, according to MIL-STD-882D standard a failure probability is categorized into five categories and failure consequences severity into four categories. There may be used 3 by 3 cells matrix or 5 by 5 cells matrix especially for simple risk assessments

\footnotetext{
a Rano Khan Wassan : rkwassan@gmail.com
}

This is an Open Access article distributed under the terms of the Creative Commons Attribution License 2.0, which permits unrestricted use, distribution, and reproduction in any medium, provided the original work is properly cited. 
[6]. For larger structure like process plants 7 by 4 cells matrix is used for risk assessment [7]. It shows variable categories for failure probability and failure consequences of risk. Similarly for wide range of rotating equipment, there is a need of generalized risk matrix model which can fit different rotating equipment risk assessment situations. Therefore, in this study generalized risk matrix is developed. Variables are suggested for failure probability or failure rate and failure consequences ranges of rotating equipment to select required number of categories for effective risk assessment.

\section{Methodology}

To develop the generalized risk assessment matrix model, some basic rules were followed [4]. Generalized consequences and probability of failure categories scale were developed. These scales are discussed in next sections.

\subsection{Development of generalized consequence scale}

The suggested consequence scales are general and can fit any risk matrix standard like MIL-STD, ASME standard etc. These are depicted in the Table 1. Variable " $y$ " is suggested, which demonstrates the consequences failure range. This variable can be given any suitable numerical value and variable can be extended from $\mathrm{y}_{1} \ldots \mathrm{y}_{\mathrm{n}}$ for nth category. This depends on how many categories are selected for the failure consequences. In the Table $1, \mathrm{C}$ represents the consequences categories $\mathrm{C}_{1} \ldots \mathrm{C}_{\mathrm{n}}$, severity of the consequences decreases from $\mathrm{C}_{1}$ to $\mathrm{C}_{\mathrm{n}}$. In Table 1, descriptive terms are used to set qualitative assumptions if numeric numbers are not available for the consequence categories. Qualitatively consequences can be named as catastrophic, critical, marginal and negligible. These category levels are examples, but can be customized further.

\subsection{Development of generalized failure rate scale}

Similarly like consequence scales, variable " $x$ " is suggested which represents failure rate ranges. Table. 2 represents generalized failure rate scale. Variable " $\mathrm{x}$ " can be extended from $\mathrm{x}_{1} \ldots . \mathrm{x}_{\mathrm{n}}$, depends on how many categories are selected for failure rate. Variable ranges given in Table 2, for failure rate are adjustable, because variables can be used for any numerical value. Organization can use their values for failure rate. In Table $2, \mathrm{P}$ represents failure rate category from $\mathrm{P}_{1} \ldots \mathrm{P}_{\mathrm{n}}$. As the number will increase from $P_{1} \ldots P_{n}$ the frequency of failure occurrence will decrease in this case. Categories from $P_{1}$ to $P_{n}$ are also given descriptive term to make qualitative assumptions in case if numeric figure are not available to set ranges. Qualitatively descriptive terms for failure rate can be defined, as frequent, probable, occasional and remote etc, but still they can be modified.

Table 1. Consequence categories scale

\begin{tabular}{|c|c|c|}
\hline Ranges & Notation & Category \\
\hline $\mathrm{C}_{1} \geq \mathrm{y}_{1}$ & $\mathrm{C}_{1}$ & Catastrophic \\
\hline $\mathrm{y}_{1}>\mathrm{C}_{2}>\mathrm{y}_{2}$ & $\mathrm{C}_{2}$ & Critical \\
\hline $\mathrm{y}_{2}>\mathrm{C}_{3}>\mathrm{y}_{3}$ & $\mathrm{C}_{3}$ & Marginal \\
\hline$\vdots$ & $\vdots$ & $\vdots$ \\
\hline & $\mathrm{I}$ & \\
\hline $\begin{array}{c}\mathrm{y}_{\mathrm{n}-1}>\mathrm{C}_{\mathrm{n}}>\mathrm{y}_{\mathrm{n}}, \\
\mathrm{C}_{\mathrm{n}} \leq \mathrm{yn}_{\mathrm{n}}\end{array}$ & $\mathrm{C}_{\mathrm{n}}$ & Low \\
\hline
\end{tabular}

Table 2. Failure rate scale

\begin{tabular}{|c|c|c|}
\hline Ranges & Notation & Category \\
\hline $\mathrm{P}_{1} \geq \mathrm{x}_{1}$ & $\mathrm{P}_{1}$ & Frequent \\
\hline $\mathrm{X}_{1}>\mathrm{P}_{2}>\mathrm{x}_{2}$ & $\mathrm{P}_{2}$ & Probable \\
\hline $\mathrm{x}_{2}>\mathrm{P}_{3}>\mathrm{x}_{3}$ & $\mathrm{P}_{3}$ & Occasional \\
\hline$\vdots$ & $\vdots$ & $\vdots$ \\
\hline & $\vdots$ & \\
\hline $\begin{array}{c}\mathrm{x}_{\mathrm{n}-1}>\mathrm{P}_{\mathrm{n}}>\mathrm{x}_{n}, \\
\mathrm{P}_{\mathrm{n}} \leq \mathrm{x}_{\mathrm{n}}\end{array}$ & $\mathrm{P}_{\mathrm{n}}$ & Remote \\
\hline
\end{tabular}




\subsection{Development of generalized risk assessment matrix}

Based on risk parameters categories defined, risk matrix can be formulated using such parameters scales. The proposed risk assessment matrix is shown in Table 3. In this risk matrix the cell "P1C1" is product of catastrophic failure consequences and frequent failure rate. Each cell value in risk matrix is product of failure consequences and failure rate.

Table 3. Generalized risk assessment matrix

\begin{tabular}{|c|c|c|c|c|c|}
\hline Consequences & & & & & \\
\hline Failure rate & Catastrophic & Critical & Marginal & -- & Low \\
\hline Frequent & $\mathrm{P}_{1} \mathrm{C}_{1}$ & $\mathrm{P}_{1} \mathrm{C}_{2}$ & $\mathrm{P}_{1} \mathrm{C}_{3}$ & ir & $\mathrm{P}_{1} \mathrm{C}_{\mathrm{n}}$ \\
\hline Probable & $\mathrm{P}_{2} \mathrm{C}_{1}$ & $\mathrm{P}_{2} \mathrm{C}_{2}$ & $\mathrm{P}_{2} \mathrm{C}_{3}$ & -1 & $\mathrm{P}_{2} \mathrm{C}_{\mathrm{n}}$ \\
\hline Occasional & $\mathrm{P}_{3} \mathrm{C}_{1}$ & $\mathrm{P}_{3} \mathrm{C}_{2}$ & $\mathrm{P}_{3} \mathrm{C}_{3}$ & $\begin{aligned}-7-1 \\
1 \\
1\end{aligned}$ & $\mathrm{P}_{3} \mathrm{C}_{\mathrm{n}}$ \\
\hline $\begin{array}{l}1 \\
i\end{array}$ & $-1-1$ & $\begin{array}{c}1 \\
-1-1 \\
-1-1\end{array}$ & $\begin{array}{c}1 \\
-1- \\
1\end{array}$ & $-1--$ & $\begin{array}{l}1 \\
1 \\
1\end{array}$ \\
\hline Remote & $\mathrm{P}_{\mathrm{n}} \mathrm{C}_{1}$ & $\mathrm{P}_{\mathrm{n}} \mathrm{C}_{2}$ & $\mathrm{P}_{\mathrm{n}} \mathrm{C}_{3}$ & ---1 & $P_{n} C_{n}$ \\
\hline
\end{tabular}

Table 4. Risk categories

\begin{tabular}{|c|c|c|}
\hline Risk & \multicolumn{2}{|c|}{ Category } \\
\hline $\mathrm{P}_{1} \mathrm{C}_{1}, \mathrm{P}_{1} \mathrm{C}_{2}$, & & \\
$\mathrm{P}_{2} \mathrm{C}_{1}, \mathrm{P}_{2} \mathrm{C}_{2}$, & High & Unacceptable \\
$\mathrm{P}_{3} \mathrm{C}_{1}$ & & \\
\hline $\mathrm{P}_{1} \mathrm{C}_{3}, \mathrm{P}_{2} \mathrm{C}_{3}$, & & Undesirable \\
$\mathrm{P}_{3} \mathrm{C}_{2}, \mathrm{P}_{3} \mathrm{C}_{3}$, & Serious & \\
$\mathrm{P}_{\mathrm{n}} \mathrm{C}_{1}$ & & Acceptable \\
\hline $\mathrm{P}_{1} \mathrm{C}_{\mathrm{n}}, \mathrm{P}_{2} \mathrm{C}_{\mathrm{n}}$, & Medium & with review \\
$\mathrm{P}_{\mathrm{n}} \mathrm{C}_{2}, \mathrm{P}_{\mathrm{n}} \mathrm{C}_{3}$ & & $\begin{array}{c}\text { Acceptable } \\
\text { without } \\
\text { review }\end{array}$ \\
\hline $\mathrm{P}_{3} \mathrm{C}_{\mathrm{n}}, \mathrm{P}_{\mathrm{n}} \mathrm{C}_{\mathrm{n}}$ & Low & rieut \\
\hline
\end{tabular}

\subsection{Risk categorization}

In the risk assessment matrix in Table 3 , each cell has been given risk parameters (failure rate $\times$ failure consequences) categories. These parameters help to categorize the failures risk in such particular cells. The Table 4 shows the different ranges of cell values to categorize failures based on combined effect of failure rate and its consequence. In proposed risk assessment matrix, cell C1P1 show the high risk and it is assumed that this risk for the system is unacceptable. Similarly ranges are set for remaining cells and different categories are shown in Table 4. Further, this categorization for the risk depends on residual risk value of any organization.

\subsection{Risk assessment and risk evaluation}

Once risk assessment matrix developed, risk assessment process can be carried out based on the risk matrix assumptions for failure rate and consequences. Risk evaluation will be performed for prioritizing risks to carry out risk control activities. Large risks will require urgent treatment whilst those that are minor may require no handling at all.

\section{Results and discussions}

In this study, power generation system of the petrochemical industry was taken as case study. This power generation plant includes six gas turbines for power generation. Only one gas turbine risk assessment was carried out in this paper. The gas turbine has capacity of $35 \mathrm{MW}$ and most of the time remained in continuous operation to fulfil the required demand. Gas turbine is complex rotating equipment, so there can be various failure modes for its components.

\subsection{Failure analysis of gas turbine subsystems}

Based on available data FMEA was performed, it was observed that all failure modes resulted gas turbine unavailability. The number of failures and associated downtime per failure was extracted from plant data. Figure 1 shows the eight subsystem's failures for the system. Generator of the gas turbine failed two times and control system failures occurred three time. All other subsystems mentioned in Figure 1 have one failure throughout five years operation period of the gas turbine. 


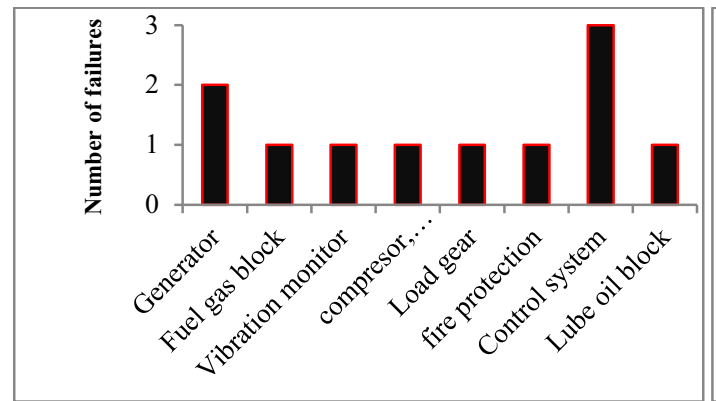

Figure 1. Number of failures

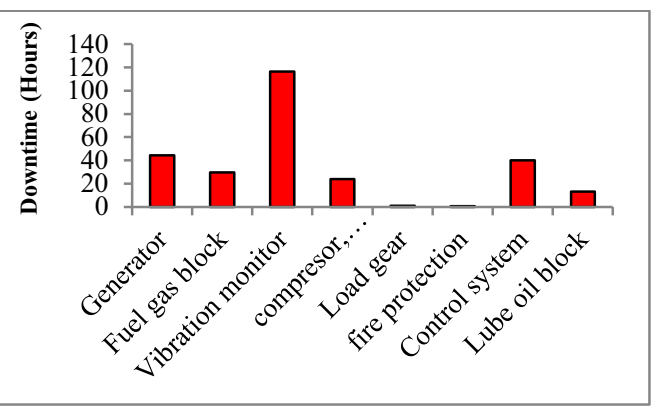

Figure 2. Downtime per failure

Figure 2 shows the gas turbine subsystem's downtime per failure. The downtime occurred due to the vibration monitor system was 116.5 hours. Generator, fuel gas block and compressor, combustion chamber and turbine have 44.4, 29.8 and 23.8 downing hours respectively. While load gear, fire protection, control system and lube oil block have $0.5,0.9,40$ and 13 hours downtime respectively. In terms of downtime, higher consequences were due to the vibration monitor subsystem failures. Generator subsystem has second high consequences when it failed.

\subsection{Developing failure consequence scale for gas turbine subsystems}

Different failures of gas turbines subsystems may have similar or different consequences severity impact. To categorize the consequences severity of the failures, downtime ranges were suggested. The ranges assumed for failure consequences are shown in Table 5. Four categories of consequences in terms of the downtime hours due to failure were assumed.

\subsection{Developing failure rate scale for gas turbine subsystems}

Based on the available operational and maintenance data from the plant, failure rates of the gas turbine subsystems were estimated numerically. Failure rates were categorized based on studies carried out for the gas turbine risk assessment [8]. Table 6 shows the scale used for the gas turbine subsystems failure rates. In Table 6 failure ranges are per year for gas turbine subsystems.

Table 5. Failure consequence scale [8]

\begin{tabular}{|c|c|c|}
\hline $\begin{array}{c}\text { Failure consequences in } \\
\text { terms of downtime } \\
\text { hours/failure }\end{array}$ & Notation & Category \\
\hline$>1000$ & $\mathrm{C} 1$ & Catastrophic \\
\hline$>100$ but $<1000$ & $\mathrm{C} 2$ & Critical \\
\hline$>10$ but $<100$ & $\mathrm{C} 3$ & Marginal \\
\hline$<10$ & $\mathrm{C} 4$ & Negligible \\
\hline
\end{tabular}

Table 6. Failure rate scale [8]

\begin{tabular}{|c|c|c|}
\hline $\begin{array}{c}\text { Failure rate } \\
\text { ranges }\end{array}$ & Notation & Category \\
\hline$>1 \mathrm{f} /$ year & $\mathrm{P} 1$ & Frequent \\
\hline $1-0.1 \mathrm{f} /$ year & $\mathrm{P} 2$ & Probable \\
\hline $\begin{array}{c}0.1-0.01 \\
\text { f/year }\end{array}$ & $\mathrm{P} 3$ & Occasional \\
\hline $\begin{array}{c}0.01-0.001 \\
\text { f/year }\end{array}$ & $\mathrm{P} 4$ & Remote \\
\hline$<0.001 \mathrm{f} /$ year & $\mathrm{P} 5$ & Improbable \\
\hline
\end{tabular}

\subsection{Generalized risk assessment matrix}

The proposed general model can fit to various available risk matrix standards. Since the risk acceptable criterion is not known for gas turbine, so MIL-STD standard has been employed to categorize the subsystems failure risks. Four levels for the consequences impacts and five levels for the failure frequency were defined for gas turbine as represented in Table 5 and Table 6 respectively. For details on MIL-STD risk assessment matrix standard refer [5]. 


\subsection{Risk ranking based on risk assessment matrix}

Based on the estimated failure rate and consequence for subsystems risk matrix was developed. The actual failure rate per year and downtimes per failure of the subsystems are shown in Table 7 . Subsystems failure risks have fallen in medium, serious and high risk categories, results are depicted in Table 7. Gas turbine compressor, combustion chamber and turbine, generator, lube oil system, control system and fuel gas block were under serious risk. Only fire protection and load gear system have medium risk. Vibration monitor system has high risk, due to higher consequences. Subsystems under high and serious risks were unacceptable and needed urgent attention to minimize the risk levels. While for medium risk levels preventive action can be taken.

Table 7. Risk assessment of GT sub systems

\begin{tabular}{|c|c|c|c|c|c|}
\hline & Actual failure & Failure rate & $\begin{array}{c}\text { Actual } \\
\text { downtime } \\
\text { rate/year }\end{array}$ & $\begin{array}{c}\text { Failure } \\
\text { consequences } \\
\text { downtime hour } \\
\text { ranges }\end{array}$ & Total risk \\
\hline $\begin{array}{c}\text { Compressor, Combustion } \\
\text { chamber, Turbine }\end{array}$ & 0.22 & $1-0.1 \mathrm{f} /$ year & 24 & $10-100$ & Serious \\
\hline Fire Protection & 0.24 & $1-0.1 \mathrm{f} /$ year & 1 & $0-10$ & Medium \\
\hline Generator & 0.72 & $1-0.1 \mathrm{f} /$ year & 45 & $10-100$ & Serious \\
\hline Lube Oil & 0.25 & $1-0.1 \mathrm{f} /$ year & 13 & $10-100$ & Serious \\
\hline Fuel Gas & 0.25 & $1-0.1 \mathrm{f} /$ year & 30 & $10-100$ & Serious \\
\hline Load gear & 0.20 & $1-0.1 \mathrm{f} /$ year & 2 & $0-10$ & Medium \\
\hline Vibration monitor & 0.20 & $1-0.1 \mathrm{f} /$ year & 117 & $100-1000$ & High \\
\hline Control system & 0.68 & $1-0.1 \mathrm{f} /$ year & 40 & $10-100$ & Serious \\
\hline
\end{tabular}

\section{Conclusions}

It was observed that total eight subsystems of power generation were under risk. Vibration monitoring was having high risk, five subsystems were under serious risk and two under medium risk categories based on the risk matrix ranking. This study can be further extended for maintenance planning of subsystems based on their associated risk.

\section{Acknowledgement}

Author would like to thank Department of Mechanical Engineering, Universiti Teknologi PETRONAS for supporting this research study.

\section{References}

1. E. F. William, "Forsthoffer's Rotating Equipment Handbooks: Fundamentals of Rotating Equipment," (2005).

2. N. F. Rieger, "The High Cost of Failure of Rotating Equipment," co DTIC, p. 3, (1990).

3. G. F. M. de Souza, Thermal Power Plant Performance Analysis: Springer, (2012).

4. A. S. Markowski and M. S. Mannan, "Fuzzy risk matrix," Journal of hazardous materials, vol. 159, pp. 152-157, (2008).

5. M. DoD, "882D Standard Practice for System Safety," US Department of Defense, (2000).

6. B. Ruge, "Risk matrix as tool for risk assessment in the chemical process industries," ESREL 2004, (2004).

7. O. Salvi and B. Debray, "A global view on ARAMIS, a risk assessment methodology for industries in the framework of the SEVESO II directive," Journal of hazardous materials, vol. 130, pp. 187-199, (2006).

8. J. D. Andrews and T. R. Moss, Reliability and risk assessment: Longman Scientific \& Technical, (1993). 